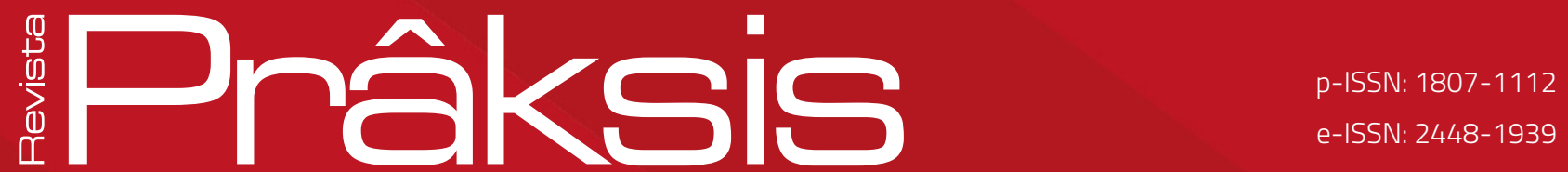

Recebido em: 24 de setembro de 2018 Aprovado em: 15 de dezembro de 2018 Sistema de Avaliação: Double Blind Review RPR | a. 16|n. 1 | p. 243-271 | jan./abr. 2019 DOI: https://doi.org/10.25112/rpr.v1i0.1692

\title{
A EVOLUÇÃo BIOLÓGICA Na PERSPECTIVA DE ESTUDANTES DO CURSO DE CIÊNCIAS BIOLÓGICAS DA UNIUERSIDADE FEEVALE
}

BIOLOGICAL EVOLUTION IN THE STUDENT

PERSPECTIVE OF THE BIOLOGICAL SCIENCES

COURSE OF THE FEEVALE UNIVERSITY

Cristiane Borba Luckmann

Graduanda do Curso de Ciências Biológicas da Universidade Feevale (Novo Hamburgo/Brasil).

E-mail: crisbluck@hotmail.com.

\section{Natalia Aparecida Soares}

Doutora em Ensino de Ciências pela Universidade Luterana do Brasil (Canoas/Brasil).

Professora na Universidade Feevale (Novo Hamburgo/Brasil) e na Escola Profissional Unipacs (Taquara/Brasil).

E-mail: nataliasoares@feevale.br. 


\section{RESUMO}

A evolução biológica é amplamente mencionada nos documentos norteadores da educação nacional, inclusive sendo citada como eixo unificador dos conteúdos de Ciências Naturais. No entanto, observaram-se em investigações científicas que ainda são latentes as barreiras epistemológicas e didáticas para o ensino de evolução. Diante deste cenário, buscou-se, através deste estudo, analisar as concepções e saberes científicos de estudantes do curso de Ciências Biológicas da Universidade Feevale acerca da evolução biológica, seleção natural e diversidade de espécies, identificando as principais influências formadoras dessas opiniões, realizando uma análise comparativa entre as concepções de ingressantes e egressos do curso, com o objetivo de verificar a construção do conhecimento científico na graduação. Como metodologia, optou-se por uma abordagem quanti-qualitativa exploratória, através da coleta de dados com o uso de questionários semiestruturados, adaptados de pesquisas recentes. 0 grupo analisado foi composto por 39 estudantes, sendo 15 ingressantes e 24 egressos, a maioria bacharel (60\%). Através dessa pesquisa, constatou-se que os estudantes apresentam entendimento incipiente acerca da temática, com concepções errôneas de evolução biológica e seleção natural. Os resultados, de forma geral, demonstraram que os alunos compreendem a Biologia Evolutiva como um conjunto de processos que permitem a melhoria e/ou aprimoramento de características anatômicas e fisiológicas dos organismos vivos. Observou-se, ainda, que as concepções sobre a teoria evolucionista são influenciadas pelos preceitos religiosos dos estudantes, onde há constante dicotomia entre ciência e religião e diretamente ligados ao ensino deficiente da temática na educação básica. Considera-se pertinente o fomento de discussões sobre a história da ciência e suas contribuições diretas para o desenvolvimento da sociedade contemporânea, acredita-se que este debate possa corroborar para amenizar alguns conflitos culturais apresentados por alguns estudantes que entendem a evolução como oposta às suas convicções pessoais.

Palavras-chave: Biologia evolutiva. Ensino de ciências naturais. Concepções. Ensino superior. Ciências biológicas.

\section{ABSTRACT}

Biological evolution is widely mentioned in guiding documents of the national education, including being cited as unifying axis of the contents of the Natural Sciences. However, it was observed in scientific investigations they are still latent the barriers epistemological and didactic for the teaching of evolution. In this scenario, we sought through this study to analyze the conceptions and scientific knowledge of students in the course of Biological Sciences of Feevale University about biological evolution, natural selection and species diversity, identifying the main forming influences of these opinions, performing a comparative analysis between the conceptions of beginners and graduates of the course, with the objective of verifying the construction of scientific knowledge in the graduation. As a methodology we chose a exploratory quantitative-qualitative approach, through the collection of data with the use of structured questionnaires, adapted from recent searches. The analyzed group was composed of 39 students, being 15 beginners and 24 graduates, the majority bachelor (60\%). Through this research, we found that the students have an incipient knowledge about the theme, with misconceptions of biological evolution and natural selection. The results, in general, have demonstrated that students understand the Evolutionary Biology as a set of processes that allow the improvement and/or enhancement of anatomical and physiological characteristics of living organisms It was also observed that the conceptions of evolutionary theory are influenced by religious precepts of students, where there is constant dichotomy between science and religion and are directly related to a deficiency at the teaching this topic in basic education. It is pertinent the promotion of discussions on the history of science and its direct contributions to the development of contemporary society, it is believed that this debate can corroborate to alleviate some cultural conflicts presented by some students who understand the evolution as opposition to their personal convictions.

Keywords: Evolutionary biology. Teaching of natural sciences. Conceptions. Higher education. Biological sciences. 


\section{INTRODUÇÃO}

Atualmente, a evolução biológica encontra-se na Base Nacional Curricular Comum - BNCC (BRASIL, 2017) como conceito unificador de conteúdos de Ciências Naturais, sendo essencial para o entendimento desta área da Biologia. Além disso, o assunto tem ganhado destaque no Exame Nacional do Ensino Médio (ENEM) dos últimos anos e, portanto, é fundamental aprofundar o ensino desta temática, pois é através do estudo dessa área que o aluno pode conhecer e compreender a história da vida em nosso planeta.

A evolução biológica, segundo Futuyma (2009, p. 4), "num sentido mais amplo, significa descendência com modificação" e, nesse contexto, está de acordo com Ridley $(2006$, p. 28) que diz:

Evolução significa mudança, mudança na forma e no comportamento dos organismos ao longo das gerações. As formas dos organismos, em todos os níveis, [...] podem ser modificadas a partir daquelas dos seus ancestrais durante a evolução.

O ensino de teorias evolutivas traz grandes desafios, tais como conciliar visões científicas e religiosas, considerando-se que as concepções cristãs acerca da origem da vida podem dificultar que os professores trabalhem este conteúdo de forma imparcial e, conforme Oleques (2010, p. 18) salienta, "muitos não ensinam para evitar questões polêmicas", tendo como resultado uma abordagem didático-pedagógica vaga desta temática. Nesse sentido, Oliveira e Bizzo (2011, p. 21) destacam que "é essencial um currículo que privilegie esclarecimentos acerca da natureza da ciência para que os alunos compreendam as distinções entre conhecimentos científicos, religiosos, culturais e filosóficos", para que se tornem mais objetivos ao analisar fatos e teorias, proporcionando uma melhor construção dos seus saberes.

Além da religião, variáveis socioeconômicas e culturais, bem como disponibilidade de recursos educacionais são fatores que apresentam influência na construção do conhecimento científico, fato esse apoiado por Oliveira e Bizzo (2015, p. 22) quando afirmam que "os estudantes possuem visões de mundo moldadas em espaços sociais e culturais e que determinam sua maneira de pensar e agir diante de temas científicos".

Como referencial teórico para este estudo, fez-se o uso das obras de Ridley (2006), Futuyma (2009) e Meyer e El-Hani (2005) para introduzir o tema e explanar sobre as teorias evolucionistas, incluindo as contribuiç̧ões de Campos et al. (2013). Nas subseções que abordaram a questão da influência de crenças religiosas, os principais estudos que colaboraram para a fundamentação teórica incluíram Silva (2012), Mota (2013), Oliveira e Bizzo (2016) e Oliveira, Bizzo e Pellegrini (2016). Para referenciar o ensino de Ciências Naturais e ensino de Evolução biológica, destacam-se as publicações de Licatti (2005), Marandino (2015), Delizoicov, Angotti e Pernambuco (2011), Bizzo (2012) e Oleques (2010 e 2014).

Este trabalho é resultado do recorte de uma pesquisa mais ampla, realizada para o TCC de Licenciatura em Ciências Biológicas da Universidade Feevale e apresenta conceitos de evolução e seleção natural, além 
das teorias evolutivas. Através deste, pretende-se identificar os conhecimentos que os ingressantes e egressos da graduação em Ciências Biológicas da Universidade Feevale têm acerca do tema. Através de uma pesquisa quanti-qualitativa exploratória com uso de um questionário combinado, tabulação e análise de dados, espera-se conhecer as principais concepções dos estudantes sobre a evolução biológica, bem como as influências que contribuíram para a construção desses saberes em um curso de Ciências Biológicas.

\section{REFERENCIAL TEÓRICO}

A Evolução Biológica é caracterizada pelas alterações nas características hereditárias de populações de seres vivos através de gerações, resultando em mudanças nestas populações e, consequentemente, na diversificação das espécies ao longo do tempo. De acordo com Futuyma (2009, p. 4), "um sistema em evolução é simplesmente aquele que descende de uma entidade, de uma geração para outra, ao longo do tempo, e no qual as características das entidades diferem através das gerações".

Portanto, evolução consiste em mudança; são alterações genéticas, anatômicas e comportamentais que ocorrem ao longo de várias gerações, acumulando-se no decorrer dos anos, resultando em linhagens visivelmente diferentes, que levam então ao surgimento de novas espécies. Ridley (2006, p. 28) afirma, acerca dessas mudanças, que:

As formas dos organismos, em todos os níveis, desde sequências de DNA até a morfologia macroscópica e o comportamento social, podem ser modificadas a partir daquelas dos seus ancestrais durante a evolução.

O processo de evolução biológica tem sido alvo de grandes controvérsias no decorrer da história. Porém, atualmente, diante de tantas evidências que cada vez mais provam a modificação de espécies ao longo do tempo, tornou-se difícil abandonar as ideias evolucionistas por uma ciência estática como as ideias criacionistas ou fixistas propostas pelos religiosos.

\subsection{TEORIAS EVOLUCIONISTAS}

Diversas teorias surgiram ao longo dos anos, mas todas concordam que as mudanças são a chave para a diversidade que existe hoje. Meyer e El-Hani (2005, p. 18) afirmam:

As teorias da evolução biológica propõem, portanto, que os seres vivos não são imutáveis: aqueles que são vistos atualmente nem sempre existiram, nem sempre tiveram a mesma forma e nem sempre existirão. 
As principais teorias que são de importância para esta pesquisa são o Lamarckismo, uma das primeiras a explicar a evolução das espécies; o Darwinismo, que nos apresenta principalmente a proposta da Seleção Natural; e Neodarwinismo, que une a proposta de Darwin às descobertas genéticas de Mendel e que é seguida atualmente. Estas três teorias serão brevemente discutidas nesta seção.

0 primeiro mecanismo proposto na teoria de Lamarck diz que os seres vivos deveriam adaptar-se ao meio onde vivem para poder sobreviver, ou seja, ele acreditava que o ambiente tinha influência sobre a evolução dos seres vivos, apesar de sua percepção diferir muito do que se entende atualmente.

O ambiente forçaria os seres vivos a modificar seus hábitos, devido às necessidades de sobrevivência, e essa mudança de hábitos resultaria em uma alteração dos padrões de uso e desuso dos órgãos (MEYER; EL-HANI, 2005, p. 22).

Deste modo, a adaptação, do ponto de vista de Lamarck, está ligada à lei do uso e desuso, cuja definição diz que o uso contínuo de uma determinada estrutura orgânica promoveria o seu desenvolvimento, enquanto o não-uso promoveria a sua atrofia.

Espécies em ambientes diferentes têm necessidades diferentes, e então usam certos órgãos e apêndices mais do que outros. Os órgãos exercitados com maior intensidade atraem mais do "fluido nervoso", o qual os aumenta; inversamente, órgãos menos usados tornam-se menores (FUTUYMA, 2009, p. 18).

Outro mecanismo utilizado por Lamarck era a herança de características adquiridas, onde frequentemente usou o exemplo do pescoço da girafa para discutir suas concepções. Segundo Ridley (2006, p. 31-32):

[...] as girafas ancestrais haviam se esticado para atingir folhas mais altas nas árvores. $\mathrm{O}$ esforço fez com que seus pescoços se tornassem levemente maiores. Seus pescoços mais longos foram herdados pela sua prole [...] depois de muitas gerações de alongamento de pescoço, o resultado foi o que vemos hoje.

Isto é, Lamarck acreditava que todas as características adquiridas pela lei do uso e desuso seriam transmitidas aos descendentes e, além disso, sugeria que a evolução ocorria por desejo ou esforço dos organismos.

O Darwinismo reúne as ideias evolucionistas propostas por Charles Darwin. Após o retorno de sua viagem, analisando suas anotações, Darwin concluiu que as espécies se modificam e se adaptam ao longo do tempo.

Devido à luta pela vida, formas que são melhor adaptadas à sobrevivência deixam uma progênie maior e automaticamente aumentam em frequência de uma geração para outra (RIDLEY, 2006, p. 34). 
Cabe destacar que os indivíduos não mudam pela necessidade de sobreviver ou por exigências impostas pelo meio, mas, sim, de forma eventual, ou seja, as mudanças ocorrem aleatoriamente e, se trouxerem vantagens para o indivíduo, permanecerão por meio da seleção natural (CAMPOS et al., 2013).

Apesar da seleção natural se tratar de um mecanismo correto, Darwin não conseguiu explicar como as características vantajosas surgiam nos organismos e, tampouco, como eram transmitidas. Essa explicação não foi possível porque não havia conhecimento sobre Genética nesse período. Durante muitas décadas foram surgindo diversas teorias contrárias à de Darwin.

O conflito de teorias teve resolução na década de 30, com o surgimento do neodarwinismo, uma complementação da teoria de Darwin em relação às fontes de variabilidade das populações, que se tornou possível a partir de 1910 com o desenvolvimento da Genética. O neodarwinismo está baseado nas ideias do darwinismo em conjunto com as descobertas de Mendel sobre genética. De acordo com Ridley (2006, p. 38), "a síntese da teoria da seleção natural de Darwin com a teoria mendeliana da hereditariedade, feita por eles, estabeleceu o que é conhecido como neodarwinismo, teoria sintética da evolução ou síntese moderna".

Essa síntese resultou em uma teoria mais abrangente e embasada, passando a ser, portanto, mais aceita para explicar o processo evolutivo dos seres vivos e rejeitando as teorias antidarwinianas. A seleção natural, a mutação e a recombinação gênica estão dentre os principais fatores evolutivos reconhecidos pela teoria moderna da evolução.

Por fim, desde a década de 40, devido ao avanço crescente dos estudos no campo da Biologia Molecular, a pesquisa evolutiva vem acumulando evidências em direção à Teoria Moderna da Evolução, sendo que, nos últimos anos, tem se expandido em diferentes rumos, ampliando as relações entre a Genética e a Seleção natural.

\subsection{A INFLUÊNCIA DAS CRENÇAS RELIGIOSAS NAS CONCEPÇÕES E SABERES CIENTÍFICOS DE EVOLUÇÃO BIOLÓGICA}

O Brasil, nos últimos anos, vem passando por transformações sociais e culturais, com mudanças no contexto religioso onde a sociedade, que era antes denominada por Oliveira e Bizzo (2016, p. 2) "predominantemente cristã, representada pela maioria católica", atualmente é representada pelo aumento no número de evangélicos, pessoas sem religião e autodeclarados ateus. Ainda, de acordo com Neto e Fernandes (2014, p. 5), "a religião durante muito tempo teve um domínio ímpar e ainda exerce considerável influência social".

A pesquisa de Silva $(2012$, p. 91) revela que "a formação religiosa tem pouca influência sobre a visão de evolução dos indivíduos", justificando as respostas dos estudantes com o teor polêmico da temática. 
Outro ponto em sua pesquisa é o público participante, dez estudantes integrantes do mesmo grupo cristão da Igreja Luterana, 50,0\% deles oriundos de Santa Catarina.

Por outro lado, a pesquisa realizada por Oliveira, Bizzo e Pellegrini (2016, p. 14), comparando estudantes brasileiros e italianos, observou que "há influência das diferentes denominações religiosas nas respostas dos jovens brasileiros e italianos" e também que "alguns grupos religiosos parecem interferir nas respostas dos jovens, reduzindo a aceitação de tópicos da teoria evolutiva". Nas questões que tratam diretamente da evolução e evolução humana, a maioria das respostas de cunho científico veio de alunos católicos ou sem religião, enquanto evangélicos de missão e pentecostais usaram a criação divina para explicar esses fatos. Na Itália, mesmo com a religiosidade, os estudantes tendem a buscar explicações científicas para a evolução, fato relacionado ao contato com a temática desde os anos iniciais da educação básica.

Em uma pesquisa realizada englobando estudantes de todos os estados brasileiros, Mota (2013) avaliou 2.365 alunos do primeiro ano do ensino médio de 84 escolas diferentes, surpreendendo-se com a receptividade das teorias evolutivas por parte dos jovens que apresentaram atitudes positivas acerca da religiosidade, pois esperava, diante dos altos índices de aceitação das crenças religiosas, maior resistência por parte dos estudantes quanto à evolução biológica. Com este estudo, mostrando que religião e ciência podem ser compatíveis, a autora concluiu que os alunos participantes da pesquisa têm maior entendimento sobre seleção natural e registros fósseis, porém, apresentam dúvidas quanto à ancestralidade comum e demonstram oposição ou incertezas em relação à origem da vida, evolução humana e tempo geológico. Ficou evidente, também, a não compreensão dos estudantes quanto à espécie humana pertencer ao Reino Animal. Por fim, constatou-se que as concepções religiosas não são o principal problema no ensino dessa temática, mas sim o teor polêmico que gira em torno do assunto.

Corroborando, Neto e Fernandes (2014, p. 10) afirmam que "o ensino de evolução é complexo, pois esse tema é extremamente abrangente em termos de conteúdos e envolve diversas áreas do conhecimento", destacando também que:

[...] o ensino de evolução ainda perpassa por questões socioculturais e históricas de sua construção e interpretação e, diante disso, torna-se necessário melhorar as práticas de ensino dessa disciplina, de forma a tornar seu ensino contextualizado e crítico, tanto na análise de sua própria história, como em suas influências na contemporaneidade (NETO; FERNANDES, 2014, p. 10).

Deste modo, pode-se perceber que, apesar de a influência religiosa ser um fator considerável para a construção das concepções e aceitação das teorias evolutivas, não pode ser dito como determinante, devendo-se levar em conta que falhas no ensino, falta de estrutura e planejamentos inadequados, além 
de diferenças nos contextos socioculturais e o teor polêmico do tema, acarretam em dificuldades em trabalhar adequadamente a Evolução Biológica.

\subsection{O ENSINO DE CIÊNCIAS NATURAIS}

Desde os anos 1970, a criação de novos cursos relacionados ao Ensino de Ciências, o número crescente de dissertações e teses e o surgimento de novas abordagens têm contribuído para o desenvolvimento desta área (MARANDINO, 2015).

Para um professor, o ato de ensinar deve abranger mais do que transmitir saberes através de conteúdos e exercícios. $O$ ensino de Ciências Naturais é construído desde os anos iniciais e cabe ao docente a identificação dos conhecimentos prévios dos alunos, bem como aproveitá-los da melhor maneira, sem esquecer a individualidade de cada um, garantindo uma aprendizagem efetiva. 0 professor não é detentor de todo o conhecimento e, neste contexto, Campos e Nigro (1999, p. 15) afirmam que:

[...] todo educador que trabalhe visando à aprendizagem significativa dos conteúdos deve estar atento ao fato de que a criança tem algo a dizer; pensa alguma coisa; vê sob uma perspectiva o fato, o fenômeno e qualquer conteúdo passivel de aprendizagem.

Delizoicov, Angotti e Pernambuco (2011, p. 131) expressam que "nenhum aluno é uma folha de papel em branco em que são depositados conhecimentos", deixando subentendido que a construção dos saberes se dá somando as contribuiç̧ões de alunos e professores, sendo que, ao final do processo, ambos terão acrescido algo aos seus conhecimentos.

Bernardes et al. (2016, p. 3) citam que é "importante destacar que o aluno é um sujeito ativo e tem grande participação na construção do conhecimento científico", ou seja, seguindo uma prática construtivista, tem-se como personagem principal da sala de aula o aluno e não o professor; este agindo apenas como mediador, auxiliando o discente na construção dos seus saberes. Conforme Delizoicov, Angotti e Pernambuco (2011, p. 125):

Reconhecer o aluno como foco da aprendizagem significa considerar que os professores têm um papel importante de auxílio em seu processo de aprendizagem, mas, sobretudo, perceber que, para de fato poderem exercer esse papel, é preciso pensar sobre quem é esse aluno.

Também vale destacar que é preciso compreender cada estudante como um ser individual, com suas próprias crenças, limitações e maneira de aprender; é necessário desenvolver a habilidade de enxergar além do grande grupo, identificando cada um. E, qualquer que seja o conteúdo, os saberes do aluno devem 
ser levados em consideração. Neste ponto, Alencar et al. (2015, p. 3), ao mencionar quão significativo é perceber os conhecimentos prévios do estudante sobre o assunto antes de trabalhá-los, concordam com Bizzo (2012, p. 66), quando este afirma que "é importante entender que sem conhecer as ideias do educando, é muito difícil transformá-lo".

Portanto, o ensino de ciências deve estimular nos alunos o desenvolvimento de explicações, confronto de opiniões, comparações de pontos de vista, e fortalecer sua capacidade de argumentação e debate, auxiliando assim a construção do seu conhecimento científico.

\subsubsection{Ensino de Evolução Biológica}

A Evolução Biológica, no ensino superior, é colocada como elemento unificador das Ciências Biológicas. As Diretrizes Curriculares Nacionais para os Cursos de Ciências Biológicas expressam que: "Os conteúdos básicos deverão englobar conhecimentos biológicos e das áreas das ciências exatas, da terra e humanas, tendo a evolução como eixo integrador." (BRASIL, 2002, p. 5).

O documento ainda destaca a importância do estudo das Ciências Biológicas, expressando a correlação dos seres vivos, afirmando que o mesmo deve proporcionar:

[...] a compreensão de que a vida se organizou através do tempo, sob a ação de processos evolutivos, tendo resultado numa diversidade de formas sobre as quais continuam atuando as pressões seletivas. Esses organismos, incluindo os seres humanos, não estão isolados, ao contrário, constituem sistemas que estabelecem complexas relações de interdependência. 0 entendimento dessas interações envolve a compreensão das condições físicas do meio, do modo de vida e da organização funcional interna próprios das diferentes espécies e sistemas biológicos (BRASIL, 2002, p. 1).

Portanto, fica evidente a necessidade de se destacar o ensino de evolução biológica, porém, muitas pesquisas indicam dificuldades ao trabalhar com a temática.

O ensino de Evolução Biológica, apesar de um importante componente nos currículos de Ciência e Biologia, sendo um eixo integrador de conteúdo, é um tema bastante polêmico e causa receio na maioria dos professores. É um assunto que tende a gerar discussões em busca de um consenso, como nos mostra Oleques (2014, p. 34) ao explanar o depoimento de um professor que afirma, em sua entrevista, não ter dificuldades em trabalhar com o tema:

[...] considerar as concepções prévias dos alunos leva a um momento de reflexão, discussão e consequentemente enxergar as possibilidades que a evolução fornece para o dia-a-dia do aluno abandonando aquele ensino conteudista e memorístico. 
Nem todos os educadores concordam com isso, e veem neste fato um verdadeiro desafio para se trabalhar a temática, pois, de acordo com Oleques (2010, p. 18), "muitos não ensinam para evitar questões polêmicas", deixando de ensinar conteúdos fundamentais para a compreensão da Ciência como um todo.

Na temática de Biologia Evolutiva, um dos obstáculos enfrentados pelos professores, conforme Nobre e Farias (2015, p. 2) declaram, é que "a falta de recursos didáticos apropriados dificulta os processos de ensino e aprendizagem", pois muitas vezes o professor conta apenas com o livro didático, onde a origem e a evolução dos seres vivos costumam ser apresentadas em poucas páginas, tendo o docente que buscar metodologias que atraiam os estudantes, tornando-os mais inquisitivos e participativos.

Outra potencial barreira para trabalhar com essa temática envolve as concepções religiosas dos alunos e às vezes da própria escola, que contrariam as teorias evolutivas, podendo gerar conflitos. De acordo com pesquisa realizada por Licatti (2005), existem professores que não conseguem conciliar suas visões científicas e religiosas, mas também há aqueles que apresentam um ponto de vista mais integrador entre religião e ciência, respeitando as opiniões dos alunos e ensinando a Evolução como não sendo uma verdade absoluta, trazendo ambas concepções em um mesmo plano.

\section{METODOLOGIA}

0 procedimento metodológico adotado neste estudo foi misto, tendo uma abordagem quantiqualitativa exploratória que, de acordo com Prodanov e Freitas (2013, p. 52), "registra, analisa e ordena dados, sem manipulá-los, isto é, sem interferência do pesquisador", podendo ser classificada, portanto, na forma de levantamento, sendo a coleta dos dados através da aplicação de um questionário combinado, semiestruturado, adaptado das pesquisas de Silva (2012) e Oliveira, Bizzo e Pellegrini (2016).

Segundo Dal Farra e Lopes (2014, p. 5), "a construção de estudos com métodos mistos pode proporcionar pesquisas de grande relevância para a Educação como corpus organizado de conhecimento". Nessa abordagem, além de se produzir informações aprofundadas, trabalhando com significados, comportamentos, opiniões e expectativas, têm-se ainda dados numéricos que permitem especificar frequência de respostas e dados estatísticos.

O público participante da pesquisa foi composto por 39 estudantes do curso de Ciências Biológicas da Universidade Feevale, inscritos no ENADE (Exame Nacional de Desempenho dos Estudantes) no ano de 2017. Formam esse grupo 15 ingressantes (com até 25\% do conteúdo programático cursado) e 24 egressos (com mais de $80 \%$ concluído) do curso. Optou-se por este público por se acreditar ser possível uma verificação da construção dos saberes científicos no decorrer da graduação em Ciências Biológicas através da comparação dos dados obtidos entre ingressantes e egressos. 
O instrumento de coleta de dados consiste em dois questionários, um para cada grupo participante, caracterizados como semiaberto, por conter questões fechadas de múltipla escolha e questões abertas, que exigem a resposta mais elaborada, com a finalidade de expor a opinião do respondente, onde também foi realizada a sondagem do perfil sociodemográfico dos participantes. A aplicação dos mesmos ocorreu no $2^{\circ}$ semestre de 2017, de forma coletiva, por e-mail, sendo que os questionários foram elaborados em um site de pesquisas online, com interface simples e de fácil utilização, o Survio', e o link gerado foi enviado por e-mail.

Após a coleta, todos os dados foram tabulados e agrupados em categorias, tornando possivel a avaliação das diferentes fontes de influência na concepção dos saberes dos estudantes. As respostas foram avaliadas a partir da análise do conteúdo que, de acordo com Bardin (2011, p. 50), "procura conhecer aquilo que está por trás das palavras sobre as quais se debruça", tendo sido necessária, portanto, uma prévia classificação desses dados, agrupando-os conforme percepções e observações iguais ou parecidas, possibilitando assim uma análise de conteúdo mais coerente e eficiente.

\section{RESULTADOS E ANÁLISE}

Os participantes da pesquisa estão divididos em dois grupos: ingressantes e egressos do curso de Ciências Biológicas da Universidade Feevale, de Novo Hamburgo, no período de 2017/2, nas modalidades de licenciatura $(40 \%)$ e bacharelado $(60 \%)$. Os estudantes ingressantes estão matriculados no $1^{\circ}$ ou $2^{\circ}$ semestre do curso, enquanto os egressos estão divididos entre $07^{\circ}$ e $8^{\circ}$ semestre e graduados recentemente (Figura 1).

Figura 1 - Semestralidade no curso

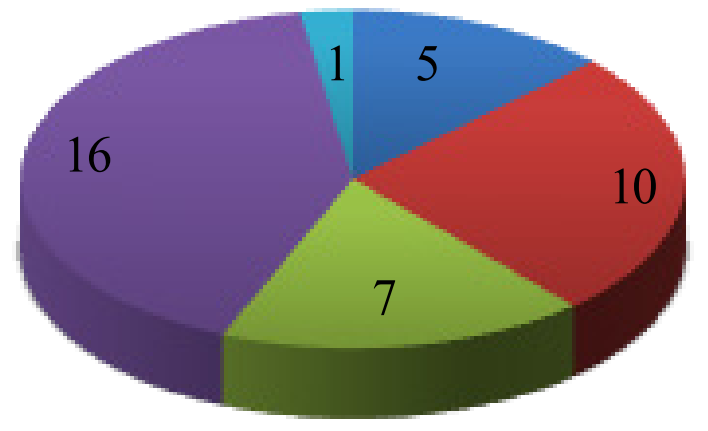

- $1^{\mathrm{o}}$ semestre

$2^{\circ}$ semestre

$7^{\circ}$ semestre

$8^{\circ}$ semestre

graduado

Fonte: dados da pesquisa (2017) 


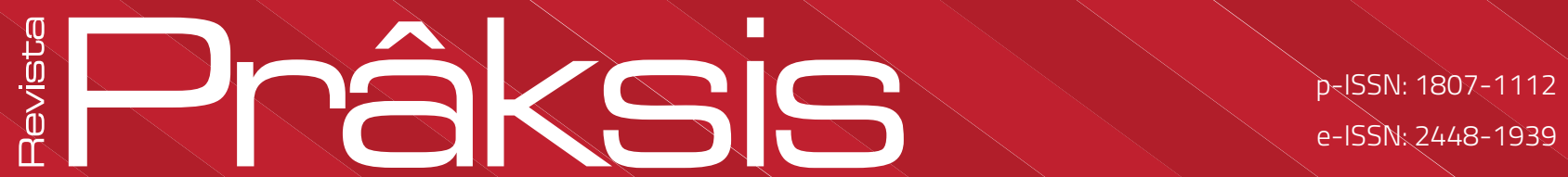

Do grupo dos ingressantes, composto de 15 estudantes, 60\% declararam-se como sendo do gênero feminino, enquanto no segundo grupo, classificado como dos egressos, os 24 estudantes estão igualmente divididos entre os gêneros feminino e masculino (Figura 2).

Figura 2 - Gênero dos participantes
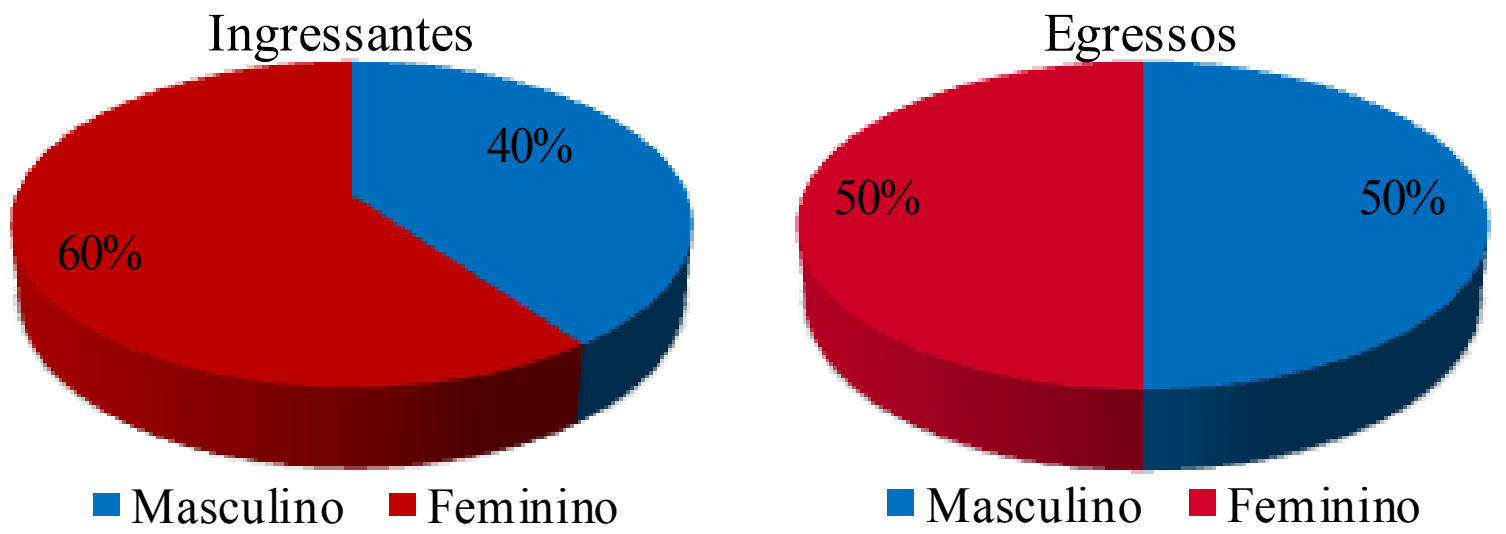

Fonte: dados da pesquisa (2017)

Com relação ao Ensino Médio, 87\% dos ingressantes e 75\% dos egressos o cursou em escola pública. Do primeiro grupo, apenas 4 respondentes declaram ter tido aulas sobre evolução, enquanto 6 estudantes afirmam não ter abordado esse conteúdo na educação básica. Neto e Fernandes $(2014$, p. 10) destacam que "o ensino de evolução é complexo, pois esse tema é extremamente abrangente em termos de conteúdo e envolve diversas áreas do conhecimento, além de encabeçar o ensino de Biologia como área integradora". Diante disso, observa-se que essa temática não vem sendo abordada adequadamente na educação básica.

Em relação às crenças religiosas, os estudantes responderam a uma questão aberta, em que a maioria diz seguir uma religião, sendo que, do total de 39 participantes, 30\% declararam-se como católicos. Entre os ingressantes, apenas 4 participantes afirmaram não possuir uma crença, sendo que 3 deles declararam-se ateus. No grupo dos egressos, a proporção de ateus e agnósticos foi menor (17 e 8\%, respectivamente), porém, houve um maior número de estudantes que têm suas crenças baseadas em valores ou em uma força imensurável, mas sem acreditar naquilo que pregam as igrejas ou ainda que não possuem uma religião ou crença definida. A divisão entre as religiões e/ou crenças mencionadas pelos respondentes pode ser acompanhada na Figura 3. 
Figura 3 - Crenças religiosas

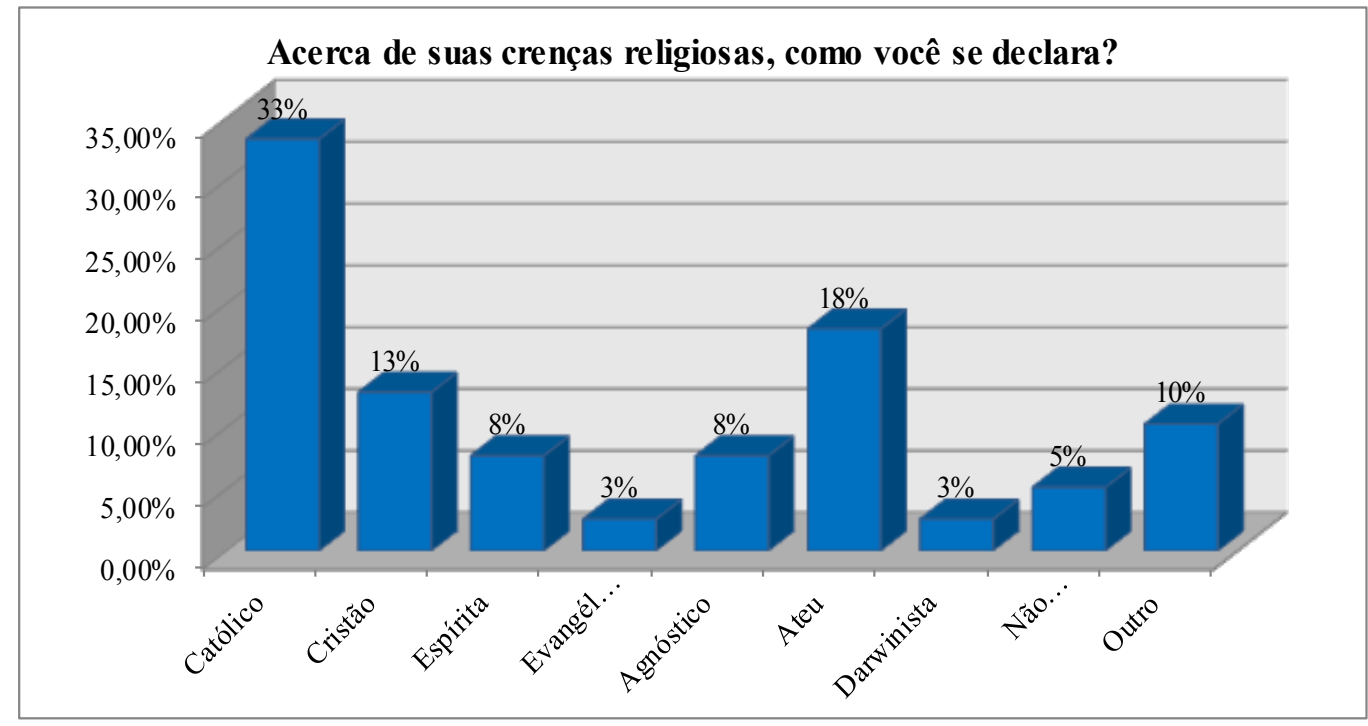

Fonte: dados da pesquisa (2017)

Nas obras consultadas, existe uma divergência quanto à influência das crenças religiosas na formação do conhecimento científico. Enquanto a pesquisa de Silva (2012, p. 91) apresenta que "a formação religiosa tem pouca influência sobre a visão de evolução dos indivíduos", sugerindo que o problema seja mais em torno da polêmica que envolve o tema, Oliveira, Bizzo e Pellegrini (2016, p. 15) consideram que "a religião, mais especificamente alguns grupos religiosos, parece interferir nas respostas dos jovens, reduzindo a aceitação de tópicos da teoria evolutiva".

Na subseção seguinte, será apresentada uma análise comparativa entre os dois grupos de estudantes, diante das questões abertas e fechadas, comuns aos dois questionários.

\subsection{ANÁLISE COMPARATIVA ENTRE ESTUDANTES INGRESSANTES E EGRESSOS}

A maioria dos estudantes (67\%) de ambos os grupos vê a evolução biológica como um fato, porém, diante da primeira questão aberta específica da temática, que solicitava aos estudantes sua opinião sobre o que é a evolução biológica, apenas sete ingressantes e onze egressos apresentaram respostas que se aproximam do que Ridley (2006, p. 28) diz: "Evolução significa mudança, mudança na forma e no comportamento dos organismos ao longo das gerações". As respostas dos participantes foram agrupadas em categorias e subcategorias, e encontram-se dispostas no Quadro 1. 


\section{Quadro 1 - Concepções dos acadêmicos sobre a Evolução Biológica}

\begin{tabular}{|c|c|c|c|c|}
\hline Categoria & Subcategoria & Ocorrência & $\begin{array}{l}\text { Frequência } \\
\text { Ingressantes }\end{array}$ & $\begin{array}{l}\text { Frequência } \\
\text { Egressos }\end{array}$ \\
\hline \multirow{4}{*}{$\begin{array}{l}\text { Modificações } \\
\text { sofridas pelos } \\
\text { seres vivos } \\
\text { ao longo do } \\
\text { tempo }\end{array}$} & $\begin{array}{l}\text { Modificações genéticas / mudanças das } \\
\text { características de uma geração para a } \\
\text { outra, hereditariamente. }\end{array}$ & $\begin{array}{l}19,113,115 \\
\text { E5, E6, E10, } \\
\text { E17, E18 }\end{array}$ & $20 \%$ & $21 \%$ \\
\hline & $\begin{array}{l}\text { Processo de mudanças ou } \\
\text { transformações nos seres vivos ao } \\
\text { longo do tempo. }\end{array}$ & 16,112 & $13 \%$ & ---- \\
\hline & Mudança das espécies. & 15,114 & $13 \%$ & ---- \\
\hline & $\begin{array}{l}\text { Processo através do qual ocorrem } \\
\text { mudanças ou transformações nos seres } \\
\text { vivos ao longo do tempo, podendo } \\
\text { originar novas espécies. }\end{array}$ & $\begin{array}{l}\text { E7, E12, E14, } \\
\text { E15, E24 }\end{array}$ & ---- & $21 \%$ \\
\hline \multirow{3}{*}{$\begin{array}{l}\text { Adaptação e } \\
\text { sobrevivência } \\
\text { das espécies }\end{array}$} & $\begin{array}{l}\text { Evolução dos seres vivos ao longo do } \\
\text { tempo, adaptando-se ao meio em que } \\
\text { vivem. }\end{array}$ & $\begin{array}{l}12,13,14,17, \\
\text { E1 }\end{array}$ & $26 \%$ & $4 \%$ \\
\hline & $\begin{array}{l}\text { Mudança para melhor adaptação dos } \\
\text { seres vivos. }\end{array}$ & $\begin{array}{l}\text { E2, E3, E4, } \\
\text { E8, E11, E19, } \\
\text { E20, E22 }\end{array}$ & ---- & $34 \%$ \\
\hline & $\begin{array}{l}\text { Onde o mais apto sobrevive e passa } \\
\text { suas características aos descendentes. }\end{array}$ & 110 & $7 \%$ & ---- \\
\hline $\begin{array}{l}\text { Explicação para } \\
\text { diversidade } \\
\text { biológica }\end{array}$ & $\begin{array}{l}\text { Estudo da história da vida e dos } \\
\text { processos que levaram à sua unidade e } \\
\text { diversidade. } \\
\text { É o que explica a diversidade biológica. }\end{array}$ & E9, E23 & ---- & $8 \%$ \\
\hline $\begin{array}{l}\text { Fenômeno de } \\
\text { Deus }\end{array}$ & $\begin{array}{l}\text { Fenômeno pré-estabelecido por Deus } \\
\text { desde a criação do mundo. }\end{array}$ & 18 & $7 \%$ & ---- \\
\hline $\begin{array}{l}\text { Teoria sobre } \\
\text { ancestralidade }\end{array}$ & $\begin{array}{l}\text { Uma teoria que explica a vida, a } \\
\text { hereditariedade, lança luz sobre a } \\
\text { formação de ossos, organização } \\
\text { dos nervos, a partir de evidências } \\
\text { evolutivas, fósseis, etc. }\end{array}$ & I16, E16 & $7 \%$ & $4 \%$ \\
\hline
\end{tabular}




\begin{tabular}{|l|l|l|l|l|}
\hline Categoria & Subcategoria & Ocorrência & $\begin{array}{l}\text { Frequência } \\
\text { Ingressantes }\end{array}$ & $\begin{array}{l}\text { Frequência } \\
\text { Egressos }\end{array}$ \\
\hline $\begin{array}{l}\text { Sequência de } \\
\text { fenômenos }\end{array}$ & $\begin{array}{l}\text { Uma sequência de fenômenos } \\
\text { comprovados pela ciência. }\end{array}$ & E21 & ---- & $4 \%$ \\
\hline $\begin{array}{l}\text { Não soube } \\
\text { responder }\end{array}$ & ------- & $11, E 13$ & $7 \%$ & $4 \%$ \\
\hline
\end{tabular}

\section{Fonte: dados da pesquisa (2017)}

Durante essa investigação constatou-se que um número baixo de estudantes (I9, I13, I15, E5, E6, E10, E17, E18) relaciona a evolução biológica como o processo de modificações hereditárias sofridas pelos seres vivos ao longo do tempo. Dentre os demais, enquanto alguns citam a evolução simplesmente como modificações nas espécies, outros relacionam as mudanças ocorridas no decorrer dos anos à vontade divina, deixando explícita sua crença no criacionismo.

Neste contexto, Oliveira, Bizzo e Pellegrini (2016, p. 14) afirmam que "há estudantes brasileiros que, independentemente do conhecimento sobre os processos evolutivos, preferem explicar a diversidade biológica a partir de crenças pessoais". Corroborando com isso, Neto e Fernandes (2014, p. 2) dizem:

Os próprios professores encontram muitas dificuldades em ensinar a Teoria da Evolução, principalmente por ser difícil se desvincular de seus próprios conceitos religiosos e por tratarem separadamente as teorias científicas das teorias religiosas.

De acordo com Oleques (2014, p. 75), "a maioria dos alunos apresenta um entendimento sobre o processo evolutivo centrado na seleção natural" e isso pode ser observado nas respostas de 12, 13, 14, 17, I10, E1, E2, E3, E4, E8, E11, E19, E20, E22, que relacionam a adaptação e sobrevivência das espécies com o conceito de evolução biológica, indo ao encontro do que Futuyma (2009, p. 24) retrata: "Que é a conjunção de mutação e a seleção natural que causa evolução adaptativa".

Ridley (2006, p. 28-29) define a evolução como "mudança entre gerações de uma linhagem de populações", e diz ainda que "a evolução da vida vem ocorrendo em um padrão de árvore, ramificado. A variedade moderna de espécies foi gerada pela bipartição repetida de linhagens desde um único ancestral comum de todos os seres vivos" (RIDLEY, 2006, p. 29).

Diante da segunda questão, que perguntava sobre a seleção natural, a maioria dos participantes apresentou respostas envolvendo termos como "adaptação" e "sobrevivência", o que se mostra coerente com o que Campos et al. (2013, p. 19) colocam sobre o assunto: 
[...] seleção natural nada mais é que um processo cíclico de sobrevivência e reprodução diferencial, ou seja, os mais aptos sobrevivem em maior número e, por consequência, reproduzem-se em maior número, havendo, ao longo das gerações, uma acumulação de características na população, que poderá formar uma nova espécie. A seleção natural não é aleatória, mas é relativa, isto porque o conceito de "mais apto" varia de ambiente para ambiente, isto é, um ser mais apto num dado ambiente pode não o ser noutro, diferente.

Porém, os respondentes que melhor expressaram o conceito de seleção natural, associando corretamente o fato de um organismo apresentar uma determinada característica vantajosa para sua sobrevivência em um ambiente e, devido a isso, possuir maiores taxas de reprodução, passando essa característica a seus descendentes, foram E2, E3, E5, E9, E11, E22, E24, como pode ser observado na categorização das respostas dispostas no Quadro 2.

\section{Quadro 2 - Concepções dos acadêmicos sobre a seleção natural}

\begin{tabular}{|c|c|c|c|}
\hline Categoria & Ocorrência & $\begin{array}{l}\text { Frequência } \\
\text { Ingressantes }\end{array}$ & $\begin{array}{l}\text { Frequência } \\
\text { Egressos }\end{array}$ \\
\hline Adaptação e sobrevivência dos mais aptos. & $\begin{array}{l}11,12,14,15,16,17,18 \\
19,114, E 4, E 6, E 7, E 8, \\
\text { E12, E14, E17, E18, } \\
\text { E19, E20, E22, E23 }\end{array}$ & $60 \%$ & $50 \%$ \\
\hline $\begin{array}{l}\text { Teoria / Mecanismo de evolução, diversidade e } \\
\text { mutação proposto por Darwin e Wallace. }\end{array}$ & $\begin{array}{l}\text { I12, I13, I15, E10, } \\
\text { E13, E16, E21 }\end{array}$ & $20 \%$ & $16 \%$ \\
\hline $\begin{array}{l}\text { Seleção de caracteres determinantes ou seleção de } \\
\text { organismos mais adaptados, que reproduzem-se, } \\
\text { passando as características a seus descendentes. }\end{array}$ & $\begin{array}{l}\text { E2, E3, E5, E9, E11, } \\
\text { E22, E24 }\end{array}$ & ---- & $30 \%$ \\
\hline $\begin{array}{l}\text { A seleção natural em um indivíduo ou a nível } \\
\text { populacional pode gerar novas características ou } \\
\text { provocar o reaparecimento de alguma característica. }\end{array}$ & E1 & ---- & $4 \%$ \\
\hline Não soube responder. & $13,110, \mid 16$ & $20 \%$ & ---- \\
\hline
\end{tabular}

Fonte: dados da pesquisa (2017) 
Diante disso, pode-se observar que nenhum ingressante apresentou uma resposta mais elaborada sobre a seleção natural, partindo, portanto, dos egressos as melhores definições para o conceito, ainda que, em minoria, apresentando maior concordância com Ridley (2006, p. 30):

Seleção natural significa que alguns indivíduos da população tendem a contribuir com uma descendência maior para a próxima futura geração do que outros. [...] qualquer atributo de um organismo que o leve a deixar mais descendentes do que a média terá frequência maior na população com o passar do tempo.

Campos et al. (2013) afirmam que a seleção natural ocorre quando um indivíduo apresenta variantes genéticas que the conferem maiores chances de sobrevivência e reprodução em determinado ambiente e não quando os seres vivos deliberadamente se adaptam às condições ambientais impostas pelo meio.

Sobre o conceito de biodiversidade, de maneira geral, pode-se dizer que grande parte dos estudantes apresenta uma visão coerente. Apesar da pluralidade de respostas, a maioria possui o mesmo contexto: biodiversidade é a variedade de espécies de seres vivos existentes. A categorização das respostas encontra-se disposta no Quadro 3.

\section{Quadro 3 - Concepções dos acadêmicos sobre biodiversidade}

\begin{tabular}{|c|c|c|c|}
\hline Categoria & Ocorrência & $\begin{array}{l}\text { Frequência } \\
\text { Ingressantes }\end{array}$ & $\begin{array}{l}\text { Frequência } \\
\text { Egressos }\end{array}$ \\
\hline $\begin{array}{l}\text { Soma da riqueza de espécies e abundância dos } \\
\text { indivíduos dessas espécies que compõem determinado } \\
\text { ecossistema. A diversidade de espécies só foi possível } \\
\text { devido às forças evolutivas, como a seleção natural. }\end{array}$ & E1 & ---- & $4 \%$ \\
\hline $\begin{array}{l}\text { Diversidade que compreende todas as formas de vida. } \\
\text { Conjunto de espécies de seres vivos existentes. } \\
\text { Variedade de espécies e ecossistemas. } \\
\text { Riqueza e variedade do mundo animal. }\end{array}$ & $\begin{array}{l}\text { I3,14,15,16, I7, I8, 19, } \\
\text { I10,I12, I13,I14, E2, } \\
\text { E5, E6, E7, E8, E10, } \\
\text { E11, E12, E14, E15, } \\
\text { E18, E19, E20, E21, } \\
\text { E23, E24 }\end{array}$ & $60,0 \%$ & $25 \%$ \\
\hline Uma biblioteca de genes. & E16 & ---- & $4 \%$ \\
\hline Diversidade de espécies de um local. & I2, I16, E3, E4, E17 & $13,3 \%$ & $13 \%$ \\
\hline $\begin{array}{l}\text { Conjunto de ambientes (biomas) e espécies (fauna e } \\
\text { flora). }\end{array}$ & E22 & ---- & $4 \%$ \\
\hline
\end{tabular}




\begin{tabular}{|l|l|l|l|}
\hline Categoria & Ocorrência & $\begin{array}{l}\text { Frequência } \\
\text { Ingressantes }\end{array}$ & $\begin{array}{l}\text { Frequência } \\
\text { Egressos }\end{array}$ \\
\hline $\begin{array}{l}\text { É a diversidade de seres vivos, plantas, animais, } \\
\text { seres humanos, o próprio ecossistema onde habitam. }\end{array}$ & E13 & ---- & $4 \%$ \\
\hline Não soube responder. & I1, E9 & $6,7 \%$ & $4 \%$ \\
\hline
\end{tabular}

\section{Fonte: dados da pesquisa (2017)}

Pode-se perceber que apenas alguns estudantes (I1, E9, E16) não possuem uma visão clara desse conceito, porém, a resposta de um egresso (E13) chama a atenção por indicar que o estudante, apesar de concluinte do curso, aparenta não classificar os seres humanos como animais. Isso vai de encontro ao que Henrique (2012, p. 61) aponta:

[...] parte dos alunos sabe comentar sobre a evolução humana [...] contudo, outra parte apresenta conceitos evolutivos errôneos [...]. Este pode ser o resultado de um ensino de Ciências e Biologia com características antropocêntricas, no qual raras são às vezes nas quais o ser humano é $[. .$.$] relacionado com os demais seres vivos.$

Contudo, cabe destacar que o respondente em questão não se trata de um estudante egresso do ensino médio, mas sim um acadêmico do $8^{\circ}$ semestre do curso de Ciências Biológicas da Universidade Feevale, que afirma já ter cursado a disciplina de evolução biológica presente na grade curricular.

De acordo com Oliveira (2009, p. 111), "os alunos tendem a questionar a evolução biológica diante de discussões com relação à origem do homem", frequentemente sendo vista na religião a melhor explicação para a origem e perfeição do homem.

Diante da questão: "A tecnologia do DNA recombinante tem usado bactérias para fabricar substâncias úteis ao homem, como insulina e alguns antibióticos. As indústrias farmacêuticas lutam para criar antibióticos cada vez mais potentes e eficazes contra diversos tipos de infecções. No entanto, o emprego de antibióticos de maneira indiscriminada, não controlada, tem sido a causa da incidência cada vez maior de patologias infecciosas resistentes ao uso dos antibióticos. Tal fato se deve:", que contava com quatro alternativas à escolha dos respondentes, menos da metade dos ingressantes acertou a resposta da questão, enquanto $75 \%$ dos egressos responderam corretamente. Um total de dez estudantes $(13,17,19,112,115,116$, E13, E14, E19, E20) optou pela alternativa que remetia a uma visão lamarckista. A distribuição das respostas pode ser conferida no Quadro 4. 


\section{Quadro 4 - Concepções sobre a resistência das bactérias aos antibióticos}

\begin{tabular}{|l|l|l|l|}
\hline Categoria & Ocorrência & $\begin{array}{l}\text { Frequência } \\
\text { Ingressantes }\end{array}$ & $\begin{array}{l}\text { Frequência } \\
\text { Egressos }\end{array}$ \\
\hline $\begin{array}{l}\text { Ocorreu seleção de linhagens de bactérias } \\
\text { resistentes aos antibióticos. }\end{array}$ & $\begin{array}{l}\text { I1, I2, I4, I5, I6, I8, I14, E1, } \\
\text { E2, E3, E4, E5, E6, E7, E8, } \\
\text { E11, E12, E15, E16, E17, } \\
\text { E18,E21, E22, E23, E24 }\end{array}$ & $46 \%$ & $75 \%$ \\
\hline $\begin{array}{l}\text { Há uma tendência das bactérias de se } \\
\text { habituarem aos antibióticos, ficando mais } \\
\text { resistentes. }\end{array}$ & $\begin{array}{l}13,17,19,112,115,116, E 13, \\
\text { E14, E19, E20 }\end{array}$ & $40 \%$ & $17 \%$ \\
\hline $\begin{array}{l}\text { O antibiótico provoca o aumento da parede } \\
\text { celular bacteriana, tornando-a resistente. }\end{array}$ & $113, \mathrm{E9}$ & $7 \%$ & $4 \%$ \\
\hline $\begin{array}{l}\text { A adição de antibiótico induziu o aparecimento } \\
\text { de bactérias mais fortes. }\end{array}$ & $110, \mathrm{E} 10$ & $7 \%$ & $4 \%$ \\
\hline
\end{tabular}

\section{Fonte: dados da pesquisa (2017)}

A maior parte dos egressos participantes associou corretamente a resistência das bactérias aos antibióticos, como sendo resultado do mecanismo de seleção natural, proposto por Darwin. Porém, dentre os ingressantes, 40\% retratou ideias Lamarckistas na escolha da resposta, expressando que, conforme Meyer e El-Hani (2005, p. 22), "o ambiente forçaria os seres vivos a modificar seus hábitos, devido às necessidades de sobrevivência". Silva (2012) cita que é preocupante o desconhecimento dos estudantes acerca da resistência bacteriana e diz que isso aponta possíveis falhas no ensino de Ciências e Biologia na educação básica.

Aúltima questão consistiu em uma série de afirmações às quais os respondentes deveriam caracterizar como verdadeiras ou falsas. As afirmações e considerações dos participantes podem ser observadas no Quadro 5. 


\section{Quadro 5 - Afirmações sobre evolução biológica e as considerações dos participantes}

\begin{tabular}{|c|c|c|c|c|c|c|}
\hline \multirow{2}{*}{ Afirmações } & \multicolumn{3}{|c|}{ Ingressantes } & \multicolumn{3}{|c|}{ Egressos } \\
\hline & v & $\mathbf{F}$ & NSD* & $\mathbf{v}$ & $\mathbf{F}$ & NSD* \\
\hline $\begin{array}{l}\text { A formação do planeta Terra se deu há cerca de 4,5 } \\
\text { bilhões de anos. }\end{array}$ & $93 \%$ & ---- & $7 \%$ & $79 \%$ & $4 \%$ & $17 \%$ \\
\hline $\begin{array}{l}\text { Os primeiros seres vivos surgiram nos oceanos há cerca } \\
\text { de } 3,5 \text { bilhões de anos. }\end{array}$ & $80 \%$ & $7 \%$ & $13 \%$ & $59 \%$ & $8 \%$ & $33 \%$ \\
\hline $\begin{array}{l}\text { A vida surgiu a partir de reações químicas numa Terra } \\
\text { primitiva. }\end{array}$ & $47 \%$ & $13 \%$ & $40 \%$ & $54 \%$ & $13 \%$ & $33 \%$ \\
\hline $\begin{array}{l}\text { Deus é o responsável pelas variações ocorridas nas } \\
\text { espécies ao longo dos tempos.** }\end{array}$ & $27 \%$ & $53 \%$ & $20 \%$ & $13 \%$ & $58 \%$ & $29 \%$ \\
\hline $\begin{array}{l}\text { Os fósseis são evidências de seres vivos que viveram no } \\
\text { passado. }\end{array}$ & $100 \%$ & ---- & ---- & $100 \%$ & ---- & ---- \\
\hline $\begin{array}{l}\text { As espécies atuais de animais e plantas se originaram } \\
\text { de outras espécies do passado. }\end{array}$ & $100 \%$ & ---- & ---- & $100 \%$ & ---- & ---- \\
\hline $\begin{array}{l}\text { O desaparecimento de uma espécie ocorre em } \\
\text { consequência de sua transformação em outra, nova. }\end{array}$ & $13 \%$ & $74 \%$ & $13 \%$ & $17 \%$ & $79 \%$ & $4 \%$ \\
\hline $\begin{array}{l}\text { As bactérias são seres menos evoluídos que grande } \\
\text { parte dos animais, considerando seu tamanho. }\end{array}$ & $20 \%$ & $73 \%$ & $7 \%$ & $17 \%$ & $79 \%$ & $4 \%$ \\
\hline $\begin{array}{l}\text { A evolução biológica ocorre tanto em plantas como em } \\
\text { animais. }\end{array}$ & $86 \%$ & $7 \%$ & $7 \%$ & $100 \%$ & ---- & ---- \\
\hline $\begin{array}{l}\text { O acaso tem um importante papel na Evolução } \\
\text { Biológica. }\end{array}$ & $40 \%$ & $33 \%$ & $27 \%$ & $75 \%$ & $17 \%$ & $8 \%$ \\
\hline $\begin{array}{l}\text { A espécie humana descende de outra espécie de } \\
\text { primata. }\end{array}$ & $73 \%$ & $20 \%$ & $7 \%$ & $88 \%$ & $8 \%$ & $4 \%$ \\
\hline $\begin{array}{l}\text { A espécie humana habita a terra há cerca de } 100.000 \\
\text { anos. }\end{array}$ & $34 \%$ & $33 \%$ & $33 \%$ & $38 \%$ & $12 \%$ & $50 \%$ \\
\hline Organismos diferentes podem ter um ancestral comum. & $93 \%$ & $7 \%$ & ---- & $100 \%$ & ---- & ---- \\
\hline $\begin{array}{l}\text { Os primeiros seres humanos foram vítimas de } \\
\text { dinossauros carnívoros. }\end{array}$ & $7 \%$ & $53 \%$ & $40 \%$ & ---- & $83 \%$ & $17 \%$ \\
\hline $\begin{array}{l}\text { Jean Baptiste Lamarck foi um dos cientistas precursores } \\
\text { do evolucionismo. }\end{array}$ & $67 \%$ & $7 \%$ & $26 \%$ & $75 \%$ & $4 \%$ & $21 \%$ \\
\hline
\end{tabular}




\begin{tabular}{|l|l|l|l|l|l|l|}
\hline \multirow{2}{*}{ Afirmações } & \multicolumn{2}{l|}{ Ingressantes } & \multicolumn{2}{l|}{ Egressos } \\
\cline { 2 - 8 } & V & F & NSD* & V & F & NSD* \\
\hline $\begin{array}{l}\text { Uma das propostas de Lamarck foi a lei do uso e } \\
\text { desuso. }\end{array}$ & $67 \%$ & ---- & $33 \%$ & $75 \%$ & ---- & $25 \%$ \\
\hline $\begin{array}{l}\text { A teoria proposta por Darwin ainda é o que se utiliza } \\
\text { para explicar o processo evolutivo dos seres vivos e não } \\
\text { foi modificada desde sua concepção. }\end{array}$ & $60 \%$ & $20 \%$ & $20 \%$ & $38 \%$ & $37 \%$ & $25 \%$ \\
\hline $\begin{array}{l}\text { Darwin frequentemente usava o exemplo do pescoço } \\
\text { das girafas para explicar a seleção natural. }\end{array}$ & $53 \%$ & $27 \%$ & $20 \%$ & $29 \%$ & $63 \%$ & $8 \%$ \\
\hline $\begin{array}{l}\text { As descobertas de Mendel sobre genética } \\
\text { complementaram as ideias de Darwin. }\end{array}$ & $73 \%$ & $7 \%$ & $20 \%$ & $75 \%$ & ---- & $25 \%$ \\
\hline $\begin{array}{l}\text { A Evolução Biológica representa uma ameaça à fé cristã, } \\
\text { pois não está de acordo com a interpretação correta das } \\
\text { Escrituras.** }\end{array}$ & $47 \%$ & $40 \%$ & $13 \%$ & $25 \%$ & $42 \%$ & $33 \%$ \\
\hline $\begin{array}{l}\text { A teoria moderna da evolução reconhece como } \\
\text { principais fatores evolutivos a mutação, a recombinação } \\
\text { gênica e a seleção natural. }\end{array}$ & $100 \%$ & ---- & ---- & $71 \%$ & $4 \%$ & $25 \%$ \\
\hline $\begin{array}{l}* \text { Não Saberia Dizer } \\
* * \text { Como base para avaliação das respostas, considerou-se esta alternativa como falsa. }\end{array}$ & & & \\
\hline
\end{tabular}

\section{Fonte: dados da pesquisa (2017)}

Aqui, foram abordados os principais assuntos pertinentes à evolução biológica e as teorias a ela relacionadas, bem como a idade da Terra, origem da vida e surgimento da espécie humana.

Diante de muitas afirmações, vários estudantes assinalaram a alternativa "Não saberia dizer", fato este constatado também por Oliveira, Bizzo e Pellegrini (2016, p. 14), onde destacam que "os estudantes do Brasil não possuem conhecimento inequívoco para responder sobre os assuntos elencados no questionário; há percentuais altos de jovens que não souberam responder sobre os tópicos evolutivos". Portanto, considerando os participantes que deram uma resposta (verdadeiro ou falso), de maneira geral o grupo dos egressos demonstrou melhor desempenho, sendo exceção apenas nas questões da idade da Terra e tempo de vida na Terra.

Mota (2013, p. 65) afirma que os estudantes "estão propensos a discordar quando os itens versam sobre origem e evolução da Terra e do ser humano", contudo, nessa pesquisa, esse fato não foi observado, visto que sobre essas temáticas os participantes obtiveram maiores índices de acerto, demonstrando 
dificuldade apenas quanto ao tempo de existência da espécie humana, sendo que somente $33 \%$ dos ingressantes e $12 \%$ dos egressos consideraram como falso o tempo de 100 mil anos.

Além disso, como pode ser observado na afirmação que sugere a coexistência de seres humanos e dinossauros, um estudante acredita que seja verdadeiro este fato enquanto outros dez não souberam responder. Assim como na pesquisa realizada por Oliveira, Bizzo e Pellegrini (2016, p. 7), "os estudantes parecem mais incertos diante das afirmações acerca da evolução humana", não reconhecendo a época em que a espécie humana surgiu na Terra. De acordo com Mota (2013, p. 218), "os tópicos que abordam a evolução humana, a origem da vida e o tempo geológico apresentaram maior tendência à rejeição ou incertezas".

Observa-se que a maioria dos estudantes ingressantes não reconhece o papel do acaso na evolução biológica, havendo uma tendência a relacionar as alterações sofridas pelos seres exclusivamente às necessidades impostas pelo meio. Campos et al. (2013) retratam a evolução como uma combinação de processos aleatórios (variação genética) e não aleatórios (seleção).

Ainda nesta questão, baseando-se na pesquisa de Oliveira, Bizzo e Pelegrini (2016), considerou-se pertinente uma avaliação mais aprofundada a fim de identificar se as crenças religiosas influenciam na construção do conhecimento científico dos estudantes, relacionando estas informações com o índice de acertos dos participantes da pesquisa.

No que se refere às crenças dos participantes, cabe destacar que os respondentes que apresentaram um menor rendimento nesta questão são autodeclarados católicos ou cristãos, levando a crer que, de certo modo, a religiosidade tenha influência nas concepções científicas. Segundo Neto e Fernandes (2014, p. 1-2), "grande parte dos discentes aprendem, desde os anos iniciais, que a origem da vida ocorreu por ação divina, ao longo de um processo de criação elaborado por um criador superior".

Corroborando, Oliveira, Bizzo e Pellegrini (2016, p. 15-16) salientam que, "para alguns estudantes brasileiros, os conhecimentos religiosos parecem preencher lacunas de possiveis defasagens no conhecimento acerca da teoria evolutiva". Em contrapartida, Silva (2012, p. 34) declara que "o sentimento de polêmica seria um obstáculo considerável no tratamento do tema", e afirma ainda não ter observado uma influência das crenças religiosas, caracterizando os resultados da sua pesquisa como consequência da dicotomia da ciência e religião.

Contribuindo com isso, Mota (2013, p. 221) destaca que "as crenças religiosas não constituem a principal dificuldade enfrentada no ensino da temática", enfatizando que a polêmica que envolve o tema é a maior responsável pela abordagem inadequada por parte dos professores da educação básica e, consequentemente, pelas concepções equivocadas dos estudantes acerca da evolução biológica. 
Constatou-se ainda que, entre os participantes autodeclarados católicos e cristãos, surgiu uma tendência ao fixismo, diante da frase que afirmava Deus como responsável pelas variações sofridas pelas espécies ao longo do tempo. De acordo com Meyer e El-Hani (2005, p. 16), "além de supor que as espécies são imutáveis, a visão fixista crê num Deus criador, o qual teria originado o mundo tal como nós o vemos hoje". Além disso, é possível observar que menos da metade dos participantes (40\% dos ingressantes e $42 \%$ dos egressos) afirma que a evolução biológica não é uma ameaça à fé cristã, e dez estudantes, entre os dois grupos, declararam não saber responder. Fica evidente a dificuldade dos estudantes em relacionar a evolução humana da mesma maneira que os demais seres vivos.

Mota (2013) afirma que muitos professores apresentam dificuldades de compreender as teorias evolutivas e acabam intimidados pela polêmica que rodeia a temática, resultando em um trabalho abordado superficialmente.

Por fim, observa-se que os problemas conceituais acerca da evolução biológica se originam ainda na educação básica, seja por parte da resistência dos alunos em, devido suas próprias concepções, aceitar as teorias evolucionistas, ou por professores temerosos em abordar um tema tão polêmico em suas aulas, comprometendo o processo de ensino-aprendizagem e o desenvolvimento do conhecimento científico.

\section{CONSIDERAÇÕES FINAIS}

A evolução biológica é uma das áreas mais importantes dentro da ciência, sendo fundamental seu estudo e compreensão para que os saberes científicos possam ser construídos. É relevante reconhecer os equívocos cometidos em relação à temática, que não vem sendo adequadamente explorada como eixo unificador de conteúdos.

Ao avaliar a compreensão dos estudantes acerca dos conceitos de evolução biológica, seleção natural e diversidade de espécies, constatou-se que os ingressantes demonstraram um conhecimento superficial dos conceitos relacionados à evolução biológica e seleção natural, relacionando evolução biológica com adaptação e sobrevivência, apresentando, assim, uma ideia equivocada deste conceito.

Os estudantes egressos, por sua vez, apesar de terem exposto melhor os conceitos de seleção natural e biodiversidade, no que diz respeito à evolução biológica também demonstraram conhecimentos insuficientes, apresentando a evolução biológica como uma forma de organismos se adaptarem ao meio em que vivem e não como um processo de alterações e mutações genéticas, transmitidas hereditariamente ao longo de gerações, podendo resultar no surgimento de novas espécies. Além disso, é notória a inconsistência das respostas acerca deste conceito nas diferentes questões em que o mesmo foi abordado. 
No que diz respeito à seleção natural, por parte dos ingressantes observou-se uma tendência Lamarckista diante de algumas questões, como no caso da resistência das bactérias aos antibióticos; contudo, a maioria dos estudantes que erraram esta questão responderam corretamente quando questionados sobre o fenômeno ocorrido em alguns insetos, esta questão também se referindo à seleção natural. Estas respostas comprovam o déficit presente diante da definição desse conceito que, quando abordado em diferentes contextos, é compreendido de maneira distinta pelos estudantes.

Fica evidente que, na visão de $40 \%$ dos estudantes ingressantes no curso de Ciências Biológicas da Universidade Feevale, a seleção natural ocorre devido à necessidade dos seres vivos de uma determinada espécie se adaptarem a alguma condição imposta pelo meio em que vivem e não por uma alteração genética que, se vantajosa, será transmitida aos descendentes.

Todavia, os egressos, diante do conceito de seleção natural, apresentaram um resultado satisfatório, mostrando-nos que os estudantes deste grupo compreendem e reconhecem as teorias evolutivas que explicam o processo da evolução biológica, ainda que não tenham uma definição clara para o conceito.

Entretanto, diante da ideia de que a seleção natural atua permanentemente sobre as populações, os egressos apresentaram dificuldade em sua avaliação da afirmação, resultando em um índice relativamente baixo (58\%) de concordância. Isso pode facilmente ser relacionado ao fato de os estudantes não reconhecerem o papel do acaso - ou mesmo o significado do termo na ciência - e tenderem a considerar que qualquer processo ocorrido tenha um objetivo, uma finalidade.

Ao identificar e analisar as concepções de estudantes ingressantes e egressos, observou-se diferenças nas respostas entre os grupos diante de alguns conceitos, o que pode indicar que os mesmos estão sendo abordados na graduação de forma mais abrangente, provavelmente de maneira multidisciplinar, tornando a aprendizagem mais efetiva.

Dessa forma, tanto ingressantes quanto egressos demonstraram maior domínio diante de questões que envolviam a diversidade de espécies, considerando-se que apenas dois estudantes alegaram não saber responder e um respondeu de forma incoerente. Diante da questão aberta, as respostas respeitaram o significado do termo biodiversidade segundo os autores competentes na área. Aqui, também foi possivel observar a colocação de um estudante que listou seres vivos como "plantas, animais, seres humanos", o que pode indicar concepções formadas a partir de um conhecimento científico antropocêntrico, tendo a crença de que o homem tenha surgido a partir de criação divina.

Com relação ao tempo de existência da espécie humana, é evidente a falta de informação, visto que um número baixo de participantes (5 ingressantes e 3 egressos) posicionou-se assertivamente diante da afirmação, enquanto quase metade dos estudantes alegou não saber responder. Ainda, na 
mesma questão, diante da frase que afirmava uma relação entre seres humanos e dinossauros, um ingressante concordou e dez estudantes não souberam responder. Aqui, observa-se que é muito comum entre os estudantes a incerteza quanto ao tempo de existência da espécie humana na Terra, porém, é extremamente preocupante o fato de aceitarem a coexistência de humanos e dinossauros ou mesmo desconhecerem que de fato isso não ocorreu. Isso nos mostra quão significativa é a falha no ensino da evolução biológica e o déficit resultante na construção do conhecimento científico.

Este estudo teve como principal objetivo a identificação das concepções e saberes científicos de acadêmicos do curso de Ciências Biológicas da Universidade Feevale sobre evolução biológica, apontando as principais influências formadoras dessas opiniões. Constatou-se que o ensino básico com abordagem inadequada e deficiente da temática, as concepções baseadas em crenças religiosas, onde a opção mais válida para a origem das espécies encontra-se no criacionismo, a polêmica em torno do tema, fazendo com que o assunto seja evitado em sala de aula e a falta de preparo dos professores da educação básica para lidar com debates e discussões, muito comuns ao trabalhar com temas polêmicos, são as principais fontes de influência na formação das opiniões levantadas através desse estudo.

Além disso, é possivel caracterizar como insuficiente o estudo da evolução biológica na graduação, visto que o tema quase não é tratado com multidisciplinaridade e, mesmo sendo de tamanha importância para a área, é ensinado em uma disciplina de apenas dois créditos na licenciatura, comprometendo ainda mais o ensino da temática na educação básica.

Por fim, destaca-se a necessidade de mais estudos na área, com o objetivo de melhorar os processos de ensino e aprendizagem e, consequentemente, enriquecer as concepções científicas dos estudantes. Diante dos comentários dos participantes dessa pesquisa, é proposto que, em um novo trabalho, reavaliese os questionários utilizados nas coletas de dados, pois os mesmos foram considerados longos, sendo pertinente selecionar questões com abordagem mais ampla, para um melhor aproveitamento ao avaliar os resultados. 


\section{REFERÊNCIAS}

ALENCAR, E.J. et al. Sequência didática para o ensino de classificação e evolução biológica, v. 1, 2015. Disponivel em: <http://webcache.googleusercontent.com/search?q=cache:http://www.editorarealize. com.br/revistas/eniduepb/trabalhos/TRABALHO_EV043_MD1_SA1_ID630_01072015142253. pdf\&gws_rd=cr\&dcr=0\&ei=WjeyWoHEOMmswASYIYnwCQ> Acesso em: 03 set 2017.

BARDIN, L. Análise de conteúdo. São Paulo: Edições 70, 2011, 229 p.

BERNARDES, L.S. et al. Uso de metodologias alternativas no ensino de ciências: um estudo realizado com o conteúdo de serpentes. Revista eletrônica Ensino, Saúde e Ambiente, v. 9, n. 1, p. 63-76, 2016. Disponivel em: <http://ensinosaudeambiente.uff.br/index.php/ensinosaudeambiente/article/ view/476/234> Acesso em: 09 set. 2017.

BIZZO, N. Ciências: fácil ou difícil? 2. ed. São Paulo: Biruta, 2012, 158p.

BRASIL. Ministério da Educação. Secretaria da Educação Básica. PCN+ Ensino Médio: orientações educacionais complementares aos parâmetros curriculares nacionais (Ciências da natureza, matemática e suas tecnologias). Brasília, DF: MEC/SEB, 2002. Disponivel em: <http://portal.mec.gov.br/ seb/arquivos/pdf/CienciasNatureza.pdf> Acesso em: 10 ago. 2017. . Ministério da Educação. Secretaria de Educação Básica. Base Nacional Curricular Comum. Brasília, DF: MEC/SEB, 2017. Disponível em: <http://basenacionalcomum.mec.gov.br/images/ BNCC_20dez_site.pdf> Acesso em: 10 ago. 2017.

CAMPOS, M. C. C.; NIGRO, R. G. Didática de Ciências: o ensino-aprendizagem como investigação. São Paulo: FDT, 1999, 190p.

CAMPOS R. et al. (Org.). Um livro sobre evolução. CIBIO, Centro de Investigação em Biodiversidade e Recursos Genéticos. Porto, Portugal, 2013. Disponivel em: <http://www.s-1993.pa.internl.net/siteapps/ WordPress-960/htdocs/wp-content/uploads/2015/06/Um-livro-sobre-evolucao-11.pdf> Acesso em: 03 set. 2017.

DAL FARRA, R. A.; LOPES, P. T. C. Métodos mistos de pesquisa em educação: pressupostos teóricos. Nuances: estudos sobre Educação, v. 24, n. 3, p. 67-80, 2013. Disponível em: <http://revista.fct.unesp. br/index.php/Nuances/article/view/2698/2362> Acesso em: 29 jun .2018. 
DELIZOICOV, D.; ANGOTTI, J.A.; PERNAMBUCO, M.M. Ensino de Ciências: fundamentos e métodos. 4. ed. São Paulo: Cortez, 2011. 366p.

FUTUYMA, D. J. Biologia evolutiva. 3. ed. Ribeirão Preto: FUNPEC Editora, 2009. 830p.

HENRIQUE, R.S. Evolução Humana: o que pensam os estudantes ingressantes em um curso de Ciências Biológicas sobre o assunto? Monografia (Licenciatura em Ciências Biológicas) Universidade Presbiteriana Mackenzie, São Paulo, SP, 2012, 74f. Disponivel em: <http://www. mackenzie.br/fileadmin/Graduacao/CCBS/Cursos/Ciencias_Biologicas/10_2012/Biblioteca_TCC_ Lic/2011/10_2011/RAFAEL_DOS_SANTOS_HENRIQUE.pdf> Acesso em: 20 ago. 2017.

LICATTI, F. 0 ensino de Evolução Biológica no nível Médio: investigando concepções de professores de Biologia. 2005, 242 f. Dissertação (Mestrado em ensino de Ciências e Matemática) - UNESP, Bauru, SP, 2005. Disponível em: <https://repositorio.unesp. br/bitstream/handle/11449/90884/licatti_f_me_ bauru.pdf?sequence=1\&isAllowed=y> Acesso em: 22 ago. 2017.

MARANDINO, M. Tendências teóricas e metodológicas no Ensino de Ciências. 2015. Disponível em: $<$ https://docslide.com.br/documents/tendencias-teoricas-e-metodologicas-no-ensino-de-ciencias. html> Acesso em: 03 ago. 2017.

MEYER, D.; EL-HANI, C.N. Evolução o sentido da biologia. 1. reimp. São Paulo: Editora Unesp, 2005. 136 p. MOTA, H. S. Evolução biológica e religião: atitudes de jovens estudantes brasileiros. 2013. Tese (Doutorado em Educação) - Faculdade de Educação, Universidade de São Paulo, São Paulo, 2013. Disponivel em: <http://www.teses.usp. br/teses/disponiveis/48/48134/tde-28012014-143821/pt-br. php> .Acesso em: 08 ago. 2017.

NETO, A.L.M.; FERNANDES, H.L. Evolução e religião: perspectivas e reflexões de uma prática docente a partir de uma dualidade histórica. IV Simpósio Nacional de Ensino de Ciência e Tecnologia, Ponta Grossa, PR, 2014. Anais... Disponível em: <www.sinect.com.br/2014/down.php?id=2956\&q=1>. Acesso em: 04 ago. 2017.

NOBRE, S. B.; FARIAS, M. E. Formação continuada de professores: possibilidades e desafios para o ensino de Paleontologia na Educação Básica. X ENPEC, Águas de Lindóia, SP, 2015. Anais... Disponível em: <http://www.abrapecnet.org.br/enpec/x-enpec/anais2015/resumos/R0125-1.PDF>. Acesso em: 11 ago. 2017. 
OLEQUES, L.C. Evolução Biológica: percepções de professores de Biologia de Santa Maria, RS. Dissertação (Mestrado em Educação em Ciências) - UFSM, Santa Maria, RS, 2010, 78f. Disponível em: <http://repositorio.ufsm.br/handle/1/6642>. Acesso em: 12 ago. 2017.

A Evolução Biológica em diferentes contextos de ensino. Tese (Doutorado em Educação em Ciências: química da vida e saúde) - UFSM, Santa Maria, RS, 2014, 110f. Disponível em: <http:// repositorio.ufsm.br/handle/1/3540>. Acesso em: 12 ago. 2017.

OLIVEIRA, G.S. Aceitação/Rejeição da Evolução Biológica: atitudes de alunos da Educação Básica. Dissertação (Mestrado em Educação) Universidade de São Paulo, São Paulo, SP, 2009, 163 fls. Disponível em: <http://www.teses.usp. br/teses/disponiveis/48/48134/tde-26022010-093911/pt-br. php>. Acesso em 10 dez. 2017.

OLIVEIRA, G. S.; BIZZO, N. Aceitação da evolução biológica: atitudes de estudantes do ensino médio de duas regiões brasileiras. Revista Brasileira de Pesquisa em Educação em Ciências, v 11, nv 1, p. 57-79, 2011. Disponível em: <https://seer.ufmg.br/index.php/rbpec/article/view/2327/1726>. Acesso em: 15 ago. 2017.

A Evolução biológica e os estudantes brasileiros: conhecimento e aceitação. Revista Investigações em Ensino de Ciências, v. 20, n. 2, p. 161-185, 2015. Disponível em: <https://www. if.ufrgs.br/cref/ojs/index.php/ienci/article/vie\%20w/48/27>. Acesso em: 15 ago. 2017.

. Os jovens brasileiros e a religião: algumas características e opiniões. Revista Ciências Sociais e Religião, a. 18, n. 25, p. 172-200, Porto Alegre, 2016. Disponível em: <http://www.seer.ufrgs. br/CienciasSociaiseReligiao/article/view/63285>. Acesso em: 15 ago. 2017.

OLIVEIRA, G. S.; BIZZO, N.; PELLEGRINI, G. Evolução biológica e os estudantes: um estudo comparativo Brasil e Itália. Ciênc. educ (Bauru), Bauru , v. 22, n. 3, p. 689-705, set. 2016 . Disponivel em: <http:// www.scielo.br/scielo.php?script=sci_arttext\&pid=S1516-73132016000300689\&lng=pt\&nrm=iso>. Acesso em: 15 ago. 2017.

PRODANOV, C. C.; FREITAS, E. C. Metodologia do trabalho científico: métodos e técnicas da pesquisa e do trabalho acadêmico. 2. ed. Novo Hamburgo: Editora Feevale, 2013. 277 p. Disponível em: <http://www.feevale.br/Comum/midias/8807f05a-14d0-4d5b-b1ad-1538f3aef538/E-book\%20 Metodologia\%20do\%20Trabalho\%20Cientifico.pdf>. Acesso em: 10 set. 2017. 


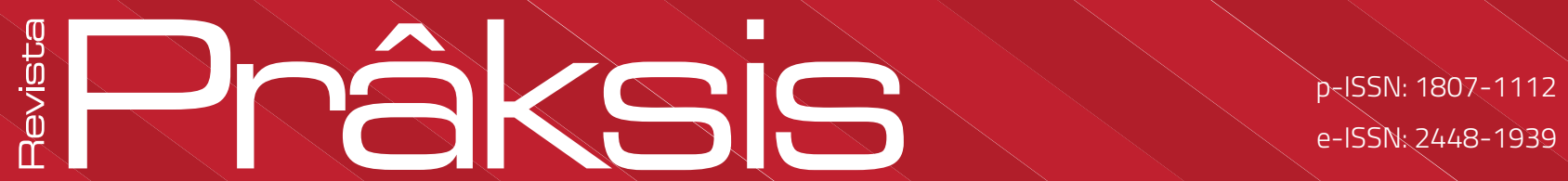

RIDLEY, M. Evolução. 3. ed. Porto Alegre: Artmed, 2006. 752 p.

SILVA, T.G.R. Concepções sobre evolução biológica entre estudantes da Universidade Federal de

Santa Catarina participantes da Missão Universitária Luterana (MUNIL). Monografia (Licenciatura em Ciências Biológicas) - Universidade Federal de Santa Catarina, Florianópolis, SC, 2012, 111f. Disponível em: <https://repositorio.ufsc.br/handle/123456789/132637>. Acesso em: 10 ago. 2017. 